\title{
Victor Hugo, Marie Tudor
}

\section{Lise Sabourin}

\section{OpenEdition}

\section{Journals}

\section{Édition électronique}

URL : http://journals.openedition.org/studifrancesi/517

DOI : 10.4000/studifrancesi.517

ISSN : 2427-5856

\section{Éditeur}

Rosenberg \& Sellier

\section{Édition imprimée}

Date de publication : 1 avril 2015

Pagination : 167

ISSN : 0039-2944

\section{Référence électronique}

Lise Sabourin, «Victor Hugo, Marie Tudor », Studi Francesi [En ligne], 175 (LIX | I) | 2015, mis en ligne le 01 avril 2015, consulté le 18 septembre 2020. URL : http://journals.openedition.org/studifrancesi/517 ; DOI : https://doi.org/10.4000/studifrancesi.517

\section{Ce document a été généré automatiquement le 18 septembre 2020}

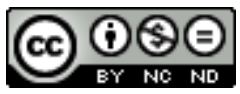

Studi Francesi è distribuita con Licenza Creative Commons Attribuzione - Non commerciale - Non opere derivate 4.0 Internazionale. 


\title{
Victor Hugo, Marie Tudor
}

\author{
Lise Sabourin
}

\section{RÉFÉRENCE}

VICTOR HUGO, Marie Tudor, édition de Clélia ANFRAY, Gallimard, 2013, «Folio théâtre», pp.

328.

1 Dans la collection de poche qui rend aisément accessibles les grandes pièces du répertoire français, Clélia Anfray donne, avec une introduction (pp. 7-42), une notice sur la genèse, la rédaction et la parution, un historique des représentations, une chronologie, des indications bibliographiques et des notes, le texte du drame consacré par Hugo à cette «reine qui soit une femme. Grande comme une reine, vraie comme une femme» qu'il veut voir en Marie Tudor («Préface», p. 47). La documentation historique ne lui fait pas défaut, mais il choisit, à l'inverse de la doxa, de voir les relations passionnelles plutôt que politiques entre la reine et son favori, Fabiano Fabiani. C'est qu'il veut «ressusciter le passé au profit du présent» («Préface», p. 47), donc tirer le mythe de la cruelle fille d'Henri VIII vers la désacralisation de la royauté marquée par 1830 , après les violences populaires régicides de 1793 . Si le drame a réussi à échapper à la censure, par crainte de redondance avec celle qui avait frappé Le Roi s'amuse, il n'en manifeste pas moins une évolution dans la dramaturgie hugolienne, conforme à l'actualité. Cette reine plus réaliste que sublime, et sans bouffon, affronte le danger des émeutes; le temps tragique se substitue discrètement au temps liturgique (les trois journées du drame donnant une résonance christique au sacrifice de l'ouvrier Gilbert); la dénonciation du pouvoir de l'argent se concentre sur le marchand juif, avatar de Shylock, selon les préjugés du temps. Tout en se référant à Corneille et Molière, Hugo, toujours placé sous l'égide shakespearienne, écrit en prose pour plus d'effet de réalité, use de didascalies prescriptives plus que descriptives, privilégie les individus pour donner «moralité et leçon» à la foule («Préface», p. 48). La version primitive du $1^{\text {er }}$ acte (donnée dans le dossier) montre que l'écriture, pour être rapide, ne lui en a pas été facile, même si, après une réception mitigée en 1833, en partie liée au jeu de Juliette Drouet dans la jeune première, Jane, quelques grands metteurs en scène $\mathrm{du} \mathrm{xx}^{\mathrm{e}}$ siècle et 
plusieurs musiciens se sont intéressés à ce drame à la dimension spectaculaire évidente. 